\title{
Süt Çocuklarında Akut Lenfoblastik Lösemi: Geriye Dönük Tek Merkez Deneyimi
}

\author{
Infant Acute Lymphoblastic Leukemia: \\ Retrospective Single-Center Experience
}

\author{
Sibel AKPINAR TEKGÜNDÜZ ${ }^{1} \mathbb{D}$, Gönül AYDOĞAN²®D, Cengiz BAYRAM ${ }^{1} \mathbb{D}$,

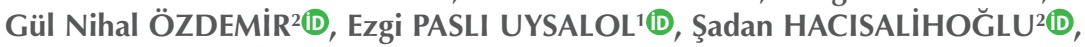 \\ Esra ARSLANTAȘ ${ }^{1} \mathbb{D}$, Ali AYÇiÇEK'미 \\ ${ }^{1}$ Başakşehir Çam ve Sakura Şehir Hastanesi, Çocuk Hematoloji-Onkoloji Kliniği, İstanbul, Türkiye \\ ${ }^{2}$ Kanuni Sultan Süleyman Eğitim ve Araştırma Hastanesi, Çocuk Hematoloji-Onkoloji Kliniği, İstanbul, Türkiye
}

\section{öz}

Amaç: Çalışmamızda allogeneik kök hücre nakli uygulanmayan süt çocuğu akut lenfoblastik lösemi olgularımızın demografik, klinik ve prognostik özelliklerini değerlendirmeyi amaçlandı.

Hastalar ve Yöntem: Bir yaş altı akut lenfoblastik lösemi tanılı olguların klinik, sitogenetik özellikleri, tedaviye yanıtları ve sağkalım süreleri geriye dönük olarak analiz edildi.

Bulgular: Çalışmaya medyan yaşı 8 (2-11) ay olan 15 (10 kız ve 5 erkek) hasta dahil edildi. 14 (\%93) hasta B-ALL ve 1 (\%7) hasta T-ALL tanısı aldı. Sitogenetik analiz sonuçları olan hastaların dördünde $(\% 40)$ t $(4 ; 11)$ saptandı. Indüksiyon tedavisi sonrası $13(\% 87)$ hastada hematolojik tam yanıt elde edildi. Çalışma sürecinde 7 (\%47) hasta hayatını kaybetti.

Sonuç: Yoğun kemoterapi uygulamalarına karşın süt çocukluğu çağında akut lenfoblastik lösemi olgularının prognozu kötüdür.

Anahtar Kelimeler: Akut lenfoblastik lösemi; Süt çocuğu; Kemoterapi

\section{ABSTRACT}

Objective: We aimed to evaluate demographic, clinic and prognostic features of patients presenting with infant acute lymphoblastic leukemia who did not receive allogeneic hematopoietic stem cell transplantation.

Patients and Methods: Clinic, cytogenetic, response and survival parameters of patients with infant acute lymphoblastic leukemia were retrospectively analyzed.

Results: The study included a total of 15 patients (10 girls, 5 boys) with a median age of 8 (1-11) months. 14 (93\%) and 1 (7\%) patients were diagnosed with B-ALL and T-ALL, respectively. 4 $(\% 40)$ of patients with available cytogenetic data showed $t(4 ; 11) .13$ (87\%) patients achieved hematological response to induction chemotherapy. Seven (47\%) patients died during study period.

Conclusion: Infants with acute lymphobalstic leukemia have poor prognosis despite intensive chemotherapy regimens.

Key Words: Acute lymphoblastic leukemia; Infant; Chemotherapy

\section{GíRiş}

Akut lenfoblastik lösemi (ALL) çocukluk çağında en sık rastlanan habis hastalıktır ve çocukluk çağı kanserlerinin \%25'ini oluşturur $(1,2)$. Günümüzde çocukluk çağı ALL olgularında çoklu ilaç içeren tedavi kombinasyonlarının akılcı kullanımı ve risk temel- 
li yaklaşım sayesinde uzun dönem sağkalım (SK) \%85-90 düzeylerine ulaşmıştır (3). Çocukluk çağı ALL olgularında tanı anında yaş ve lökosit sayısı prognostik açıdan belirleyicidir $(4,5)$. Süt çocuklarında ALL oldukça kötü prognoza sahiptir ve olguların yaklaşık üçte ikisinde KMT2A genini ilgilendiren 11q23 translokasyonu ile ilişkilidir $(6,7)$. Süt çocuğu ALL olgularında daha yoğun kemoterapi rejimleri uygulanmasına karşın uzun dönem SK sonuçları oldukça kötüdür ve beş yıllık olaysız sağkalım (OSK) oranı \%19-34 düzeylerindedir $(8,9)$.

Çalışmamızda tek merkezde ALL tanısı ile takip ve tedavi edilen ve tedavi sürecinde allogeneik kök hücre nakli uygulanmayan süt çocuklarının klinik ve prognostik özelliklerini belirlemeyi amaçladık.

\section{HASTALAR ve YÖNTEM}

Çalışmaya Ocak 2011-Mayıs 2021 tarihleri arasında tanı alan ve tek merkezde takip edilen ardışık süt çocuğu ALL olguları dahil edildi. Olgular ile ilgili tüm demografik ve klinik veriler hasta dosyalarının geriye dönük taranması ile elde edildi. Tüm olgularda tanı anında yaş, cinsiyet, akım sitometrik immunfenotip, lökosit sayısı, karyotip, FISH yöntemi ile $t(4 ; 11)$ değerlendirildi. Sayı, oran, medyan ve aralık gibi tanımlayıcı istatistik yöntemler kullanıldı. Tedavi protokolü olarak $6(\% 40)$ hastada Interfant-06 (10) ve $9(\% 60)$ hastada ALL IC-BFM 2009 (11) protokolü kullanıldı.

\section{BULGULAR}

Çalışmaya indüksiyon tedavisi olarak Interfant-06 uygulanan 6 ve ALL IC-BFM 2009 tedavisi alan 9 olmak üzere toplam 15 hasta dahil edildi. Hastalara ilişkin demografik ve klinik özellikler Tablo 1'de özetlendi. Interfant-06 protokolü uygulanan 5 (\%83.3) hastada tam remisyon sağlanırken bu hastaların biri izlem sürecinde nüks etti. Öte yandan
ALL IC-BFM 2009 tedavisi ile indüksiyon sonrası 8 (\%88.9) hastada remisyon elde edildi ve bu hastalardan biri süreç içinde nüks etti. İzlem süreci içinde Infant-06 kolunda 3 (\%50) ve ALL IC-BFM 20094 (\%44) hasta hayatını kaybetti.

İndüksiyon tedavisi sonrasında 13 (\%87) olguda hematolojik tam remisyon sağlandı. Bir hasta indüksiyon tedavisinin üçüncü günü kaybedilirken, diğer bir hasta tedaviye yanıt vermedi. Tam remisyon sağlanan iki hasta (\%15) izlem sürecinde nüks etti. Nüks sırasında bir hastada ALL, diğer hastada ise akut miyeloid lösemi saptandı. Çalışma sürecinde 7 (\%47) hasta hayatını kaybetti. Halen hayatta ve remisyonda olan 8 olguda medyan izlem süresi 45 (15-120) ay olarak gözlendi.

\section{TARTIŞMA ve SONUÇ}

Olgularımızda indüksiyon tedavisi ile \%87 oranında tam yanıt alınmasına karşın, uzun dönem takipte sağkalım oranının düşük (\%53) olduğu görüldü. Bu durum süt çocukluğu döneminde görülen ALL olgularının çocukluk çağı ALL içinde özellikle kötü prognoz ile ilişkili olduğunu ortaya koymaktadır. Süt çocukluğu dönemimde görülen ALL oldukça nadir olmasına karşın, tanı anında yüksek lökosit sayısı, merkezi sinir sistemi tutulumu, KMTA2 geninde yeniden düzenlenme ile karakterize olan ve uzun dönem yaşam beklentisinin düşük olduğu bir ALL türüdür (12). Süt çocukluğu dönemi ALL hastalarının dahil edildiği en geniş ölçekli, çok merkezli, gözlemsel Interfant-99 çalışmada dört yıllık OSK \%47 olarak gerçekleşmiştir. Benzer şekilde iki farklı çalışmada süt çocukluğu ALL olgularında beş yıllık OSK oranlarının \%19 ve \%34 düzeylerinde olduğu görülmüştür $(8,9)$. Halen tam remisyonda izlenmekte olan sekiz hastanın medyan izlem süresinin 45 ay olduğu dikkate alındığında uzun dönem SK oranımızın literatür verileri ile benzerlik gösterdiği görülmektedir.

Tablo 1. Hastaların demografik ve klinik özellikleri

Yaş (ay) (medyan; aralık)

Cinsiyet (kız; erkek) (n; \%)

İmmünfenotip (n; \%)

Tanı anında lökosit sayısı (/mm³) (n; \%)

Sitogenetik/FISH (n; \%)

Kemoterapi protokolü $(n ; \%)$

İndüksiyon tedavisi sonrası hematolojik tam yanıt (n; \%)

Nüks ( $\mathrm{n} ; \%)$

Sağ ve tam remisyonda $(n ; \%)$
$8(2-11)$

$\mathrm{KIZ}(\mathrm{n}=10 ; \% 67)$

Erkek $(n=5 ; \% 33)$

B-ALL $(n=14 ; \% 93)$

T-ALL $(n=1 ; \% 7)$

$>50000 / \mathrm{mm}^{3}(10 ; \% 67)$

$\leq 50000 / \mathrm{mm}^{3}(5 ; \% 33)$

$\mathrm{t}(4 ; 11)(\mathrm{n}=4 ; \% 27)$

$t(4 ; 17)(n=1 ; \% 7)$

Normal $(n=5 ; \% 33)$

Veri yok $(n=5 ; \% 33)$

Interfant-06 $(n=6 ; \% 40)$

ALL IC-BFM $2009(n=9 ; \% 60)$

Evet $(n=13 ; \% 87)$

Hayır $(n=2 ; \% 13)$

$\mathrm{n}=2(\% 15)$

8 (\%53) 
Hastalarımızın immünfenotipik değerlendirmesinde B-ALL olgularının (\%93) ağırlıkta olması diğer çalışma sonuçları ile uyumludur. Genel olarak süt çocukluğu ALL olguları içinde T-ALL oranı \%5'in altında görülmektedir (12). Bir yaş üzerinde akut lösemi gelişen çocuklarda erkek ağırlığı olmasına karşın, süt çocukluğu çağı lösemilerine kız çocuklarda daha sık rastlanmaktadır (13). Bizim çalışmamızda da olguların \%67'sinın kız olması beklenen bir bulgu olarak değerlendirildi. Öte yandan 10 (\%67) hastanın tanı anında lökosit sayısının $50000 / \mathrm{mm}^{3}$ olması yüksek lökosit sayıları ile seyreden süt çocukluğu ALL olguları için beklenen bir durumdur.

Süt çocukluğu ALL olgularında KMT2A geninin yeniden düzenlenmesine yol açan 11q23 translokasyonuna olguların \%70-80'inde rastlanmaktadır. Çalışmamızda sitogenetik/FISH verisi olmayan 5 hasta bulunmaktadır. Sitogenetik/ FISH verisi olan hastalar dikkate alındığında olgularımızın $\% 40$ 'ında $(n=4) \mathrm{t}(4 ; 11)$ saptanmıştır. Türkiye kaynaklı 13 süt çocuğu ALL olgusunun geriye dönük değerlendirildiği bir başka çalışmada sitogenetik değerlendirme yapılan olguların beşinde $(\% 45) \mathrm{t}(4 ; 11)$ pozitif bulunmuştur (14). Literatür verilerine kıyasla $\mathrm{t}(4 ; 11)$ anomalisinin görece daha düşük saptanması coğrafi değişikliklerle ilişkili olabileceği gibi KMT2A yeniden düzenlenmesine saptama konusunda yeni jenerasyon sekanslama gibi daha hassas yöntemlerin kullanılmaması nedeniyle bazı olgularda bu anomalinin yalancı negatif çıkmasına da bağlı olabilir.

Geriye dönük tasarım, sınırlı hasta sayısı, iki farklı kemoterapi protokolünün kullanılması ve hastaların üçte birinde sitogenetik verilere ulaşılamaması çalışmamızın önemli eksiklikleri olarak karşımıza çıkmaktadır. İlk tam remisyonda allogeneik kök hücre naklinin tedavi sonuçları üzerine etkisi halen tartışmalıdır. Allogeneik kök hücre nakli ile konsolidasyon yapılmamasına karşın uzun dönem sonuçlarımız literatür ile uyumludur. Mevcut verilerimiz bir yaş altı çocukluk çağı ALL olgularında tedavi sonuçlarının halen beklenen düzeyde olmadığı ve bu yaş grubunda daha fazla ileriye dönük çalışmaya ihtiyaç duyulduğuna işaret etmektedir.

\section{ETIK KURUL ONAYI}

Çalışma için Başakşehir Çam ve Sakura Şehir Hastanesi Klinik Araştırmalar Etik Kurulu'ndan onay alındı (Sayı: 2021.12.274).

\section{ÇIKAR ÇATIŞMASI}

Yazarların çıkar çatışması bulunmamaktadır.

\section{MALI AÇIKLAMA}

Çalışma için doğrudan veya dolaylı mali destek alınmadı. Çalışma ile ilgili herhangi bir firma veya kişi ile ilgili ticari bağlantı yoktur.

\section{YAZAR KATKISI}

Literatür taranması: SAT, GNÖ; Vakaların takip ve tedavi aşamaları: Tüm yazarlar; Verilerin toplanması: SAT, ŞH, EA; Makalenin yazımı: SAT, GA, AA; Onaylama: Tüm yazarlar.

\section{KAYNAKLAR}

1. Ward E, de Santis C, Robbins A, Kohler B, Jemal A. Childhood and adolescent cancer statistics, 2014. CA Cancer J Clin 2014;64:83103.

2. Steliarova Foucher E, Comombet M, Ries LAG, Moreno F, Dolya A, Bray F, et al. International incidence of childhood cancer, 2001-10: a population-based registry study. Lancet Oncol 2017;18:719-31.

3. Hunger SP, Mullighan CG. Acute lymphoblastic leukemia in children. N Engl J Med 2015;373:1541-52.

4. Smith M, Arthur D, Camitta B, Carroll AJ, Crist W, Gaynon P, et al. Uniform approach to risk classification and treatment assignment for children with acute lymphoblastic leukemia. J Clin Oncol 1996;14:18-24.

5. Siverman LB, Gelber RD, Dalton VK, Anselin BL, Barr RD, et al. Improved outcome for children with acute lymphoblastic leukemia: results of Dana-Farber Consortium Protocol 91-01. Blood 2001;97:1211-8.

6. Chen CS, Sorensen PH, Domer PH, Reaman GH, Korsmeyer SJ, Heerema NA, et al. Molecular arrangements on chromosome 11 q23 predominate in infant acute lymphoblastic leukemia and are associated with specific biologic variables and poor outcome. Blood 1993;81:2386-93.

7. Hilden JM, Frestedt $\mathrm{JL}$, Moore RO, Heerema NA, Arthurs DC, Reaman $\mathrm{GH}$, et al. Molecular analysis of infant acute lymphoblastic leukemia: MLL gene rearrangement and reverse transcriptase-polymerase chain reaction for $\mathrm{t}(4 ; 11)$ (q21; q23). Blood 1995;86:3876-82.

8. Dreyer ZE, Hilden JM, Jones TL, Devidas M, Winick NJ, Willman CL, et al. Intensified chemotherapy without SCT in infant ALL: results from COG P9407 (Cohort 3). Pediatr Blood Cancer 2015;62:41926.

9. Hilden JM, Dinndorf PA, Meerbaum SO, Sather H, Villaluna D, Heerema NA, et al. Analysis of prognostic factors of acute lymphoblastic leukemia in infants: report on CCG 1953 from the Children's Oncology Group. Blood 2006;108:441-51.

10. Pieters R, Lorenzo PD, Ancliffe P, Aversa LA, Brethon B, Biondi A, et al. Outcome of infants younger than 1 year with acute lymphoblastic leukemia treated with the Interfant-06 protocol: results from an international phase III randomized study. J Clin Oncol 2019;37:2246-56.

11. ALL IC-BFM 2009 protocol. Available on: www.bialaczka.org/ wp-content/uploads/2016/10/ALLIC_BFM_2009.pdf (Accessed date: 19 May 2020).

12. Brown P, Pieters R, Biondi A. How I treat infant leukemia. Blood 2019;133:205-14.

13. Howlader N, Noone AM, Krapcho M, Miller D, Altekruse SF, Kosary CL et al. SEER Cancer Statistics Review, 1975-2010. Bethesda, MD: national Cancer Institude; 2013.

14. Yaman Bajin I, Aytaç S, Kuşkonmaz B, Uçkan Çetinkaya D, Ünal S, Gümrük $F$, et al. Infant lymphoblastic leukemia: a single centers 10 year experience. Turk J Pediatr 2019;61:325-29. 